\title{
Is Cognitive Impairment a Risk Factor for Post-Stroke Depression? A Meta-Analysis Study
}

\author{
Dinda Ika Pratiwi'), Didik Tamtomo²), Bhisma Murti1) \\ ${ }^{1)}$ Masters Program in Public Health, Universitas Sebelas Maret \\ 2)Faculty of Medicine, Universitas Sebelas Maret
}

\begin{abstract}
Background: Depression is a psychiatric complication of stroke that often occurs and had a negative impact. Every year, 15 million people who experience strokes globally are at risk of developing post-stroke depression. Cognitive disorders are often associated with the presence of post-stroke depression. Understanding of risk factors for post-stroke depression can help in clinical identification and provide early intervention to improve stroke rehabilitation better. Therefore, it is very important to identify patients at risk for depression. This study aims to analyze cognitive impairment factors in the incidence of post-stroke depression.

Subjects and Method: The meta-analysis was conducted from Pubmed, Science Direct, and Springer Link databases using "stroke", "depression", "post stroke depression AND risk factor" keywords. The article chosen was an article published from January 1, 2009 to September 30, 2018. The data were analyzed using RevMan 5 program.

Results: 6 studies consisting of 3140 patients were selected for this study. The results of a meta analysis showed that cognitive impairment was a risk factor for post-stroke depression. Cognitive disorder was positively and significantly associated with post-stroke depression (OR $=1.24 ; 95 \%$ $\mathrm{CI}=1.03$ to $1.49 ; \mathrm{p}=0.02$ ).
\end{abstract}

Conclusion: Cognitive disorder is a risk factor for post-stroke depression.

Keywords: depression, post-stroke, cognitive impairment, risk factor, meta analysis

\section{Correspondence:}

Dinda Ika Pratiwi. Masters Program in Public Health, Universitas Sebelas Maret. Jl. Ir. Sutami 36 A, Surakarta 57126, Central Java. Email: dindaika.pratiwi@gmail.com.Mobile: +6281290610504.

\section{BACKGROUND}

Stroke ranks second highest cause of death in the world WHO, 2018). Brain damage that occurs is a cause of cognitive, physical, and psychological dependence and disability (Robert and Zamzami, 2014). One of the most common psychiatric complications of stroke is post-stroke depression (Qiu et al., 2018). Post-stroke depression affects a third of stroke patients at any time up to 5 years after a stroke (Ayerbe et al., 2013). Every year, 15 million people who experience strokes globally are at risk for post-stroke depression (Hackett and Pickles, 2014). The prevalence of post-stroke depression varies in several countries in the world ranging from 6\% $-79 \%$ (Tsai et al.,
2016). Depression that occurs has a negative impact on the post-stroke phase, associated with greater damage to physical and cognitive function, slowing down the rehabilitation process, increasing dependence on daily activities, decreasing quality of life, and increasing mortality when compared with patients without depression (Kutlubaev and Hackett, 2014; Volz et al., 2016). There has been a lot of consistent literature that reports negative impacts related to depression, but regarding the risk factors for depression still become a discussion.

Some researchers support that the factors underlying the occurrence of poststroke depression in addition to demographic factors, one of them is cognitive 
impairment (Terroni et al., 2012). Cognitive impairment is an unlimited intellectual decline (mild to severe damage) (Faizal et al., 2016). Disorders that occur include disorders in orientation, language, executive/ motor function, memory, attention and psychomotor speed associated with the incidence of depression (Terroni et al., 2012). Cognitive disorder is the most common risk factor associated with poststroke depression (Babkair, 2017).

Patients with cognitive function disorders need special attention in any case, because the risk of depression is likely to increase and patients cannot report the perceived symptoms (Ayerbe et al., 2013). Understanding of risk factors for poststroke depression can help in clinical identification and provide early intervention to improve outcomes and better stroke rehabilitation. Therefore, it is very important to identify patients at risk for post-stroke depression for preventive measures and appropriate treatment.

This research was conducted using a systematic review approach to studies relevant to meta-analysis. The purpose of the study is to analyze cognitive impairment factors for the incidence of poststroke depression.

\section{SUBJECTS AND METHOD \\ The strategy of database search \\ The database search uses Pubmed, Science Direct, and Springer Link published on January 1, 2009 to September 30, 2018. The keywords used are "stroke", "depress- ion", "post stroke depression AND risk factor".}

\section{Eligibility Criteria}

Eligibility criteria of the study in accordance with PICO (population, intervention, comparison, outcome):

P: Post stroke patient
I: The intervening variables were depression, assessed based on validated objective (scale of neuropsychological mood) or neuropsychiatric evaluation in accordance with the Diagnostic Statistical Manual for Mental Disorders (DSM)

C: The comparison group consisted of patients without depression.

O:Risk factors for post-stroke depression

\section{Inclusion Criteria}

Full text articles are published in English, observational studies (case control and cohort study), subjects in stroke patients, outcomes (post-stroke depression), diagnosis of depression determined by standard diagnostics or valid rating scales for depression.

\section{Exclusion Criteria}

The scale of measurement of cognitive function disorders does not use MMSE, not a multivariate analysis (AOR) study.

\section{Statistical Analysis}

Merging data in a meta-analysis was carried out to affect the estimated size of the results. All data are entered into RevMan 5. Each analysis, heterogeneity test is carried out using $\mathrm{I}^{2}$. $\mathrm{I}^{2}$ values of more than 50\% have substantial heterogeneity, then are analyzed by random effect model (REM). Less than 0.05 values are considered significant (Murti, 2018).

\section{RESULTS}

\section{The selection of the study}

The results of the overall data search obtained 461 were identified during the initial search. Multiple articles and those that did not meet the requirements were omitted so that 190 complete articles were obtained. Then the full article was examined carefully and those who did not meet the criteria were excluded, finally obtained 6 articles that met all the criteria (Farner et al., 2010; Tang et al., 2011; Ayerbe et al., 2011; Paul et al., 2013; Lewin-Richter,
} 
Pratiwi et al./ Is Cognitive Impairment a Risk Factor for Post-Stroke Depression?

2015; Shi et al., 2015) and continued

analysis with meta-analysis (Figure 1).

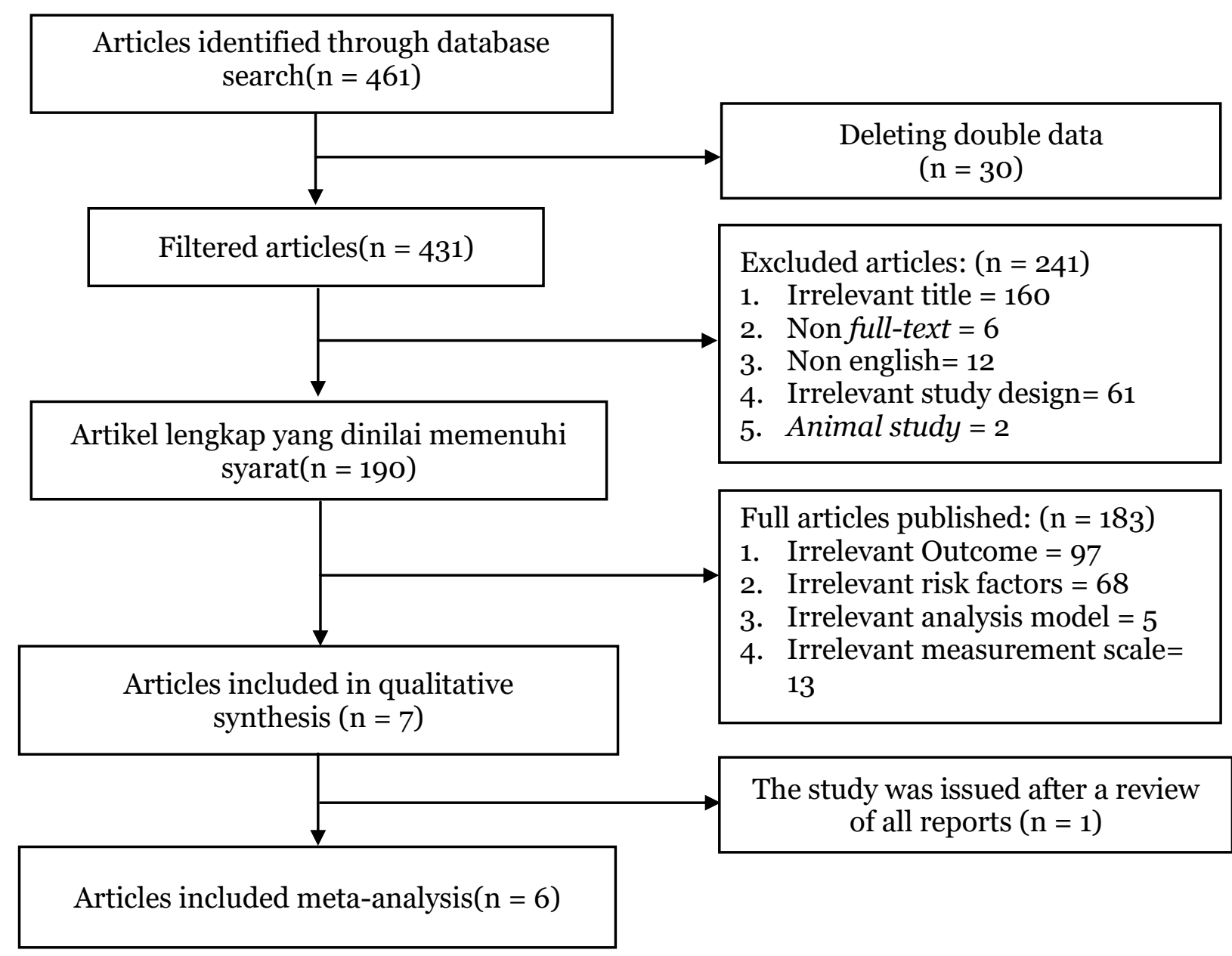

Figure 1. Study selection flow diagram

\section{Study Characteristics}

The selected study included 3140 stroke patients. The range of follow-up studies was carried out at 2 weeks up to 5 years. Stroke was diagnosed and confirmed according to WHO criteria with computed tomography (CT) or magnetic resonance imaging (MRI) (Table 1).

Based on the result of analysis, impaired cognitive function was a risk factor for post-stroke depression. The results showed a high heterogeneity between trials $\left(\mathrm{p}=0.02 ; \mathrm{I}^{2}=73 \%\right)$ so that random-effect (REM) model was used.

Cognitive disorders significantly associated with post-stroke depression which have a probability of 1.24 times higher for depression (OR 1.24; CI 95\% 1.03 to 1.49). The more severe the cognitive impairment, the higher the level of depression in poststroke patients. 
Table 1. Summary sourceof cognitive disorder and the risk of post-stroke depression

\begin{tabular}{|c|c|c|c|c|c|}
\hline $\begin{array}{l}\text { Author } \\
\text { (year) }\end{array}$ & $\begin{array}{l}\text { Type of } \\
\text { Method }\end{array}$ & Country & Total Subjects & $\begin{array}{l}\text { Follow-up } \\
\text { Duration }\end{array}$ & $\begin{array}{c}\text { Stroke and } \\
\text { Depression } \\
\text { Criteria } \\
\end{array}$ \\
\hline $\begin{array}{l}\text { Farner et al. } \\
(2010)\end{array}$ & $\begin{array}{l}\text { Cohort } \\
\text { study }\end{array}$ & Norwegia & $\begin{array}{l}\text { From } 194 \text { stroke } \\
\text { patients, only } 126 \text { who } \\
\text { could be analyzed }\end{array}$ & $\begin{array}{l}\text { 12th to } 15 \\
\text { months }\end{array}$ & $\begin{array}{l}\text { Stroke: CT } \\
\text { Depression: } \\
\text { MADRS }\end{array}$ \\
\hline $\begin{array}{l}\text { Tang et al. } \\
\text { (2011) }\end{array}$ & $\begin{array}{l}\text { Cohort } \\
\text { study }\end{array}$ & China & $\begin{array}{l}\text { From } 3219 \text { registered } \\
\text { patients, } 235 \text { who } \\
\text { fulfilled the criteria }\end{array}$ & $\begin{array}{l}3 \text { months after } \\
\text { stroke }\end{array}$ & $\begin{array}{l}\text { Stroke: CT/ MRI } \\
\text { Depression: GDS }\end{array}$ \\
\hline $\begin{array}{l}\text { Ayerbe et al. } \\
(2011)\end{array}$ & $\begin{array}{l}\text { Prospecti } \\
\text { ve cohort } \\
\text { study }\end{array}$ & England & $\begin{array}{l}\text { From } 3689 \text { registered } \\
\text { patients, only } 1821 \\
\text { patients who could be } \\
\text { followed up }\end{array}$ & $\begin{array}{l}\text { At } 3 \text { months, } 1 \\
\text { year, } 3 \text { years, } \\
\text { and } 5 \text { years. }\end{array}$ & $\begin{array}{l}\text { Stroke: Kriteria } \\
\text { WHO (CT/ MRI) } \\
\text { Depression: HADS }\end{array}$ \\
\hline $\begin{array}{l}\text { Paul et al. } \\
\text { (2013) }\end{array}$ & $\begin{array}{l}\text { Prospecti } \\
\text { ve cohort } \\
\text { study }\end{array}$ & India & $\begin{array}{l}\text { From } 853 \text { registered } \\
\text { stroke cases, } 130 \\
\text { patients matched the } \\
\text { criteria }\end{array}$ & $\begin{array}{l}8 \text { up to } 12 \\
\text { months }\end{array}$ & $\begin{array}{l}\text { Stroke: CT scan } \\
\text { Depression: DSM- } \\
\text { IV, GDS }\end{array}$ \\
\hline $\begin{array}{l}\text { Lewin- } \\
\text { Richter et al. } \\
\text { (2015) }\end{array}$ & $\begin{array}{l}\text { Prospecti } \\
\text { ve cohort } \\
\text { study }\end{array}$ & German & $\begin{array}{l}\text { From } 96 \text { stroke } \\
\text { patients, } 71 \text { patients } \\
\text { were followed up. }\end{array}$ & $\begin{array}{l}\text { At } 6 \text { months } \\
\text { after stroke }\end{array}$ & $\begin{array}{l}\text { Stroke: WHO } \\
\text { Depression: DSM- } \\
\text { IV, GDS }\end{array}$ \\
\hline $\begin{array}{l}\text { Shi Y, et al. } \\
(2015)\end{array}$ & $\begin{array}{l}\text { Prospecti } \\
\text { ve cohort } \\
\text { study }\end{array}$ & China & $\begin{array}{l}\text { From } 1095 \text { stroke } \\
\text { patients, } 757 \text { matched } \\
\text { the criteria. }\end{array}$ & $\begin{array}{l}14 \text { days, } 3 \\
\text { months, } 6 \\
\text { months, and } 1 \\
\text { year after } \\
\text { stroke }\end{array}$ & $\begin{array}{l}\text { Stroke: CT/ MRI } \\
\text { Depression: DSM- } \\
\text { IV, HRSD }\end{array}$ \\
\hline
\end{tabular}

\section{The Result of Meta-Analysis}

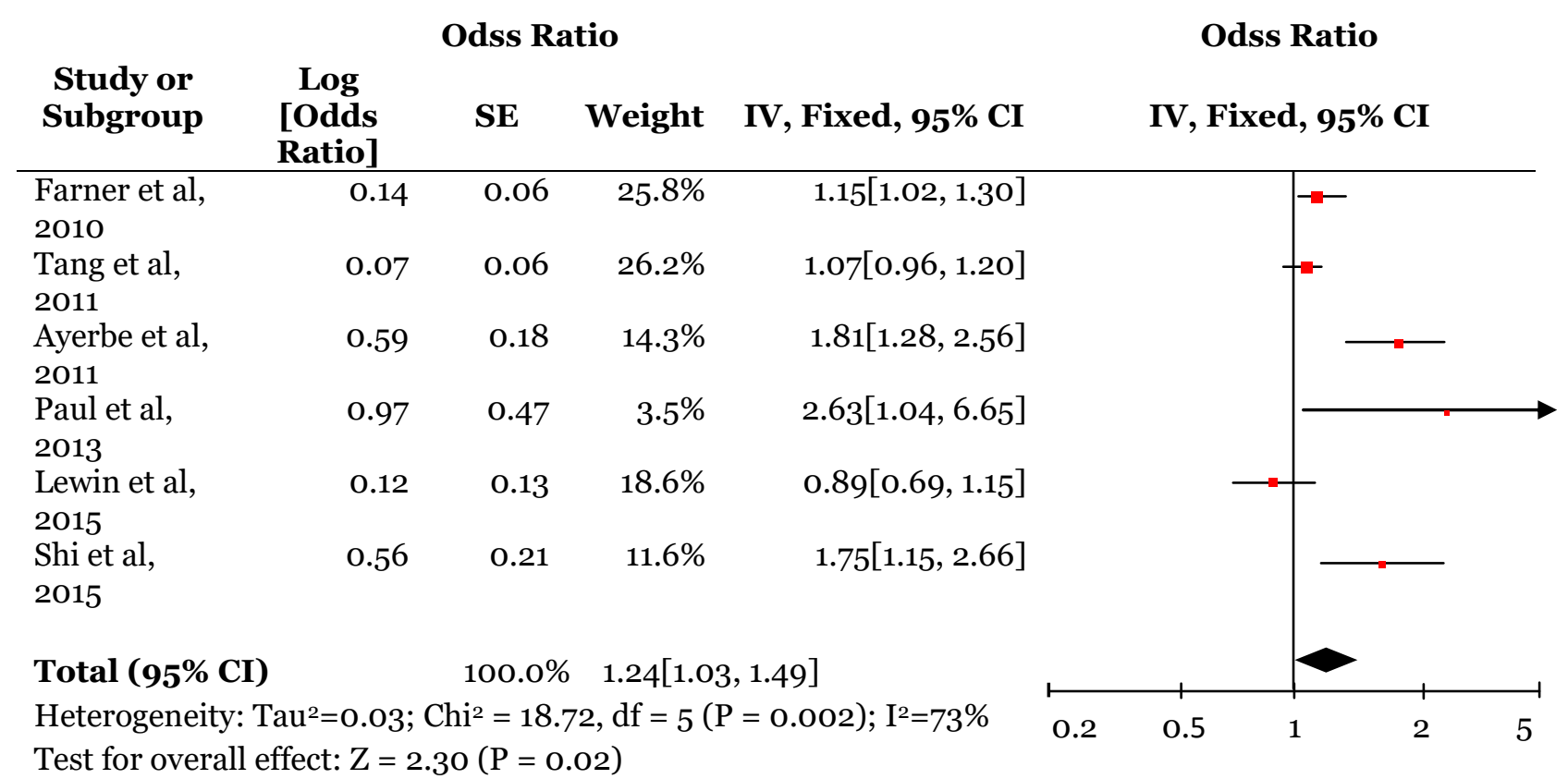

Figure 2. Forest plot meta-analysis of cognitive disorder and the risk of post-stroke depression 


\section{DISCUSSIONS}

This meta-analysis only included studies that use multivariate analysis to control confounding factors so as to strengthen the results of the study. The results of the metaanalysis of this study stated that cognitive impairment was a post-depression risk factor with a probability of 1.24 times. This was supported bysystematic review done by Robinson \& Jorge (2016)which stated thatthere was a relationship between poststroke depression and cognitive impairment/disorder. A study of Ayerbe et al., (2011)reported thatthe prevalence of depression increased by two times in patients with cognitive impairment at follow-up. Cognitive disorders were considered as manifestations of mild strokes that occurred in the first week after stroke(Shi et al., 2015).

Stroke occurred because of a lack of supply of oxygen and nutrients to the brain, which lead to biological disorder in the central nervous system (Robinson \& Jorge, 2016). Brain damage due to stroke occurred in the frontal lobe which affected memory function and intellectual function so that the patients would experience cognitive function deficits (Al-qazzaz et al., 2014). Cognitive disorders that occur include disorders of orientation, language, executive/motor function, memory, attention, and psychomotor speed which associated with the incidence of depression(Terroni et al., 2012). Feelings of helplessness due to the patient's inability in daily life and loss of motivation could trigger depression. There was a significant relationship between the level of cognitive impairment and the severity of depression (Pedroso et al., 2015).

Continuous depression would further worsen the patient's condition. Review of Ayerbe et al., (2013) stated that depression and cognitive impairment were a complex matter because both could become common risk factors for each other. Patients with cognitive impairments needed special attention in various ways, because the risk of depression was likely to increase and the patient could not recognize the symptoms. Therefore, it was highly necessaryto identify patients who were at risk through early screening of depression and provide appropriate interventions to improve rehabilitation and better stroke recovery.

This meta-analysis study has several limitations. First, the number of articles that fulfilled the criteria were only 6 articles, where the study only focused on observational studies (case control and cohort study), and was limited to multivariate analysis. In addition, only English articles that can be used because of the limitations of the author, so it was very possible to have publication bias. Thus, there were only few data that can be used effectively in the analysis. The reliability of the study was reduced due to high heterogeneity of the data.

\begin{tabular}{l}
\hline REFERENCES \\
\hline Al-qazzaz NK, Ali SH, Ahmad SA (2014). \\
Cognitive impairment and memory \\
dysfunction after a stroke diagnosis: a \\
post-stroke memory assessment. Neu- \\
ropsychiatric Disease and Treatment, \\
10: 1677-1691.
\end{tabular}

Ayerbe L, Ayis S, Rudd AG, Heuschmann PU, Wolfe CDA (2011). Natural History, Predictors, and Associations of Depression 5 Years After Stroke: The South London Stroke Register. Stroke, 42: 1907-1911.

Ayerbe L, Ayis S, Wolfe CDA, Rudd AG (2013). Natural history, predictors and outcomes of depression after stroke: systematic review and metaanalysis. The British Journal of Psy- 
Journal of Epidemiology and Public Health (2019), 4(2): 81-87

https://doi.org/10.26911/jepublichealth.2019.04.02.03

chiatry, 202(1), 14-21.

Babkair LA (2017). Risk Factors for Poststroke Depression: An Integrative Review. Journal of Neuroscience Nursing, 49(2).

Faizal M, Zulkifly M, Ghazali SE, Din NC, Kaur D, Singh A, Subramaniam P (2016). A Review of Risk Factors for Cognitive Impairment in Stroke Survivors. The Scientific World Journal, 1-16.

Farner L, Wagle J, Engedal K, Flekkøy KM (2010). Depressive symptoms in stroke patients: A 13 month follow-up study of patients referred to a rehabilitation unit. Journal of Affective Disorders, 127(1-3): 211-218.

Hackett ML, Pickles K (2014). Part I: frequency of depression after stroke: an updated systematic review and meta-analysis of observational studies. Int. J. Stroke 9, 1017-1025.

Kutlubaev MA, Hackett ML (2014). Part II: Predictors of depression after stroke and impact of depression on stroke outcome: An updated systematic review of observational studies. International Journal of Stroke, 9(8): 1026-1036.

Lewin-Richter A, Volz M, Jobges M, Werheid K (2015). Predictivity of Early Depressive Symptoms for Post-Stroke Depression. J. Nutr Health aging, 19(7): 754-758.

Murti B (2018). Prinsip dan Metodologi Riset Epidemiologi. Edisi IV. Cetakan I. Program Studi Ilmu Kesehatan Masyarakat, Program Pascasarjana, Universitas Sebelas Maret. Surakarta.

Paul N, Das S, Hazra A, Ghosal MK, Ray BK, Banerjee TP, Chaudburi A (2013). Depression Among Stroke Survivors: A Community-based, Prospective Study from Kolkata, India. Am J Geriatr Psychiatry, 21(9): 821-831.
Pedroso VSP, de Souza LC, Brunoni AR, Teixeira A (2015). Post stroke depression: Clinics, etiopathogenesis and therapeutics. Revista de Psiquiatria Clinica, 42(1), 18-24.

Qiu H, Liu Y, He H, Wu Y, He W (2018). The association between mean platelet volume levels and poststroke depression. Wiley Brain and Behavior, 8:1-7.

Robert AA, Zamzami MW (2014). Stroke in Saudi Arabia: a review of the recent literature. PanAfrican Medical Journal. 8688, 1-5.

Robinson RG, Jorge RE (2016). Post-stroke depression: A review. American Journal of Psychiatry, 173(3): 221-231.

Shi Y, Xiang Y, Yang Y, Zhang N, Wang S, Ungvari GS, Chiu HFK, et al. (2015). Depression after minor stroke: Prevalence and predictors. Journal of Psychosomatic Research, 79(2): 143147.

Shi Y, Yang D, Zeng Y, Wu W (2017). Risk Factors for Post-stroke Depression: A Meta-analysis. Frontiers in Aging Neuroscience, 9:218, 1-14.

Tang WK, Chen YK, Lu JY, Chu WCW, Mok VCT, Ungvari GS, Wong KS (2011). Cerebral Microbleeds and Depression in Lacunar Stroke. Stroke.ahajournals, 42: 2443-2446.

Terroni L, Sobreiro MFM, Conforto AB, Adda CC, Guajardo VD, Lucia MCS De, Fráguas R (2012). Association among depression, cognitive impairment and executive dysfunction after stroke. Dement Neuropsychol, 6(3): 152-157.

Tsai C, Wu C, Hung T (2016). Incidence and risk factors of poststroke depression in patients with acute ischemic stroke: A 1-year prospective study in Taiwan. Biomedical Journal, 2-7.

Volz M, Mobus J, Letsch C, Werheid K 
Pratiwi et al./ Is Cognitive Impairment a Risk Factor for Post-Stroke Depression?

(2016). The influence of early depressive symptoms, social support and decreasing self-efficacy on depression 6 months post-stroke. Journal of Affective Disorder, 206: 252-255.

WHO (2018). The top 10 causes of death.
World Health Organization Western Pacific Region.Vailable from: http://www.who.int/news-room/factsheets/detail/the-top-10-causes-ofdeath. 